\title{
Agglomeration on Food and Beverage Industry : Case study in the Province of East Java
}

\author{
${ }^{1}$ Muryani and ${ }^{2}$ Naima Janatin Akbar \\ ${ }^{1-2}$ Economics and Business Faculty
}

Airlangga University

Indonesia

\begin{abstract}
The aim of this research is to calculate and analyze the regions in East Java province that is superior in their food and beverage industries during the period of 2012-2015. The methods used in this research are Static Location Quotient (SLQ), Dynamic Location Quotient (DLQ), and Shift Share. The result of this research shows that : (1) food and beverage industries nowadays are starting to become the basis sector in almost all regencies/Cities in East Java province, (2) ) sub-sector of food and beverage is becoming the leading industries inPacitan regency, Ponorogo regency, Tulungagung regency, Blitar Regency, Kediri regency, Malang regency, Jember regency, Bondowoso regency, Situbondo regency, Sidoarjo regency, Jombang regency, Nganjuk regency, Madiun regency, Magetan Regency, Ngawi Regency, Lamongan regency, Pamekasan regency, Sumenep regency,Blitar city, and Surabaya city, (3) Ccommodity industries of food and beverage have some competitive advantages in Ponorogo regency, Tulung agung regency, Jember regency, Banyuwangi regency,Bondowoso regency, Situbondo regency,Probolinggo regency,Pasuruan regency,Jombang regency,Bojonegoro regency,Tuban regency,Lamongan regency,Bangkalan regency,Sampang regency, Pamekasan regency, Sumenep regency,Blitar city,Surabaya city, and Batu city.
\end{abstract}

Keywords: Industry, Food, Beverage, Agglomeration, East Java.

\section{INTRODUCTION}

Industrialization is the changing process from agricultural economic structure toward industrial economic structure (Sodik, 2005). Manufacturing sector nowadays are becoming the main sector to promotethe economic growth from the supply side, because this sector has a relatively fast capital investment's growth rate (Kurniati and Yanfitri, 2010). The average contribution percentage from the manufacturing sector in East Java Province for the period of 2010-2015 is 17.54\%. The contribution from manufacturing sector is also the second-biggest one after West Java Province.

Meanwhile, the average contribution from the sub-sector of food and beverage are $8.08 \%$ from the totalPDRB of $27.74 \%$ from the total process-manufacturing industry (BPS 2015). These data indicate that food and beverage industries are two examples of the vital industries in East Java province, and they still have a big potential for development, which is very suitable to be done in East Java (BPS, 2011)

Agglomeration economies or localized industries, according to Marshall begins when an industry chooses their first business location that enables them to run their business for a long time, so the surrounding societies can receive some benefits from the industry (Beenstock and Felsenstein, 2009). Glaeser, et. al. (1992) in Taringan (2005) also explained that an important element of dynamic externalitiesis knowledge spillover, where innovations and improvements that occur in a company can also increase the productivity of other companies in the same region. Knowledge spillover can be done by spreading ideas and information between companies that technologically similar to each other. 
Table 1.1.

Differences between Theories of Dynamic Agglomeration Externalities

Source : (Beger, 2001)

\begin{tabular}{|l|l|l|}
\hline Characteristic & \multicolumn{2}{|l|}{$\begin{array}{l}\text { Effect on Industrial and } \\
\text { Urban Long Run Growth }\end{array}$} \\
\cline { 2 - 3 } & MAR & Jacobs \\
\hline Specialization & + & - \\
\hline Diversity & - & + \\
\hline Competition & - & + \\
\hline
\end{tabular}

Furthermore, according to the base theory, the main factor thatdetermined economic growth in a region is the demand for goods and services from outside the region. This theory views the extent of export activities as the determinant of the rate of economic growth.

In this case, because the food and beveragesectorcontributesa substantially large percentagein the processmanufacturingindustry and the total PDRB of East Java Province,this sector is considered to be important inencourageing the acceleration of economic growth in East Java. Therefore, whether this sectoris made to become the basis industryin the city/district area or not, as well as the analysis of agglomeration in each district/cityin East Java province,is important in order to know what sector(s) should be determined to bethe leading sector in the area.

\section{RESEARCH METHODOLOGY}

\subsection{SLQ and DLQ Method}

SLQ analysis is used to determine what sectors are being the basis or non-basis in an area. Here is the equation to calculate the value of SLQ according to Tarigan (2005:35):

$$
S L Q^{t}{ }_{i r}=\frac{Y^{t}{ }_{i r} / Y^{t}{ }_{r}}{Y^{t}{ }_{i n} / Y^{t}{ }_{n}}
$$

$S L Q^{t}{ }_{i r}:$ industry's value of SLQ in year t

$Y^{t}{ }_{i r} \quad$ : PDRB from food and beverage industries in a city/region in East Java Province in year $\mathrm{t}$

$Y_{r}{ }_{r} \quad$ : PDRB from process manufacturing industryin a city/region in East Java Province in year $\mathrm{t}$

$Y^{t}{ }_{i n}$ : PDRB from food and beverage industries inEast Java Province in year $\mathrm{t}$

$Y_{n}^{t} \quad$ : PDRB from process manufacturing industryinEast Java Province in year $\mathrm{t}$

With:

1. SLQ value $>1$ for basis sector.

2. SLQ value $<1$, for the non - basis sector.

Limitation of SLQ analysis is that the basis is static and is only used to estimate sectoral changes in a given year only (Santoso et al., 2012).

DynamicLocation Quotient (DLQ) analysis is used to overcome the limitations that come up when using SLQ analysis. Here is the equation to calculate the value of DLQ according toKadariyah(1994):

$$
D L Q=\left\{\frac{\left(1+g_{i n}\right) /\left(1+g_{n}\right)}{\left(1+G_{i}\right) /(1+G)}\right\}^{t}
$$

DLQ : Value of DLQ inEast Java province in year $\mathrm{t}$

$g_{\text {in }}$ : Average growth rate offood and beverage industries in a city/region in East Java Province in year $\mathrm{t}$

$g_{n} \quad$ : Average growth rate ofprocess manufacturing industry in a city/region in East Java Province in year t

$G_{i} \quad:$ Average growth rate of food and beverage industries inEast Java Province in year $\mathrm{t}$

$G \quad$ : Average growth rate of process manufacturing industry inEast Java Province in year $\mathrm{t}$ 
With:

1. DLQ value $>1$, if the $i$ industry has the potential to grow faster than the same industry in another area in East Java province

2. DLQ value $<1$, if the $i$ industry has the potential to grow slower than the same industry in another area in East Java province

Table 2.1.

LQ Classifications (for SLQ and DLQ)

Source : Kuncoro (2000:70)

\begin{tabular}{|c|c|c|}
\hline LQ & \multirow{2}{*}{ SLQ $>1$} & \multirow{2}{*}{ SLQ $<1$} \\
\hline LQ & & \\
\hline $\begin{array}{l}\text { DLQ } \\
>1\end{array}$ & $\begin{array}{l}\text { Leading } \\
\text { industries }\end{array}$ & Key industries \\
\hline $\begin{array}{l}\text { DLQ } \\
<1\end{array}$ & $\begin{array}{l}\text { Prospective } \\
\text { industries }\end{array}$ & $\begin{array}{l}\text { Underdeveloped } \\
\text { industries }\end{array}$ \\
\hline
\end{tabular}

Table 2.1. can be described as follows:

1. If SLQ > 1 and DLQ > 1it is the leading industries.

2. If SLQ $>1$ and DLQ $<1$, it isprospective industries.

3. If SLQ $<1$ and DLQ $>1$, it iskey industries.

4. If SLQ $<1$ and DLQ $<1$, it isunder-developed industries.

\subsection{Shift Share Method}

Shift share analysis provides a more detailed explanation by describing the industry's growth factors in a particular area in relation to the national economy (Tarigan, 2005: 85). Shift Share Analysisalso provides an understanding in the selection of leading industries/sectors in an area. This analysis is relevant to be used in a regional and sectoral analysis.

Here is the equation of value component:

$\mathrm{C}_{\mathrm{ij}} \quad$ : Competitive value component

$$
C_{i j}=Y_{i j} \times\left(r_{i j}-r_{i n}\right)
$$

$\mathrm{Y}_{\mathrm{ij}} \quad$ : PDRB from food and beverage industries in $i$ city/region in East Java Province

$\mathrm{r}_{\mathrm{ij}} \quad$ : Growth rate offood and beverage industries in $i$ city/region in East Java Province

$r_{\text {in }} \quad$ : Growth rate offood and beverage industries in East Java Province

According to Rupasingha and Patrick (2010) in Setiono (2011), if the competitive value component is positive, then that region can increase the employment rate in the industry. But if the competitive value component is negative, then that region can't increase the employment ratein the industry because itdoesn'tneed a lot of labor force.

Irmawati (2016) also said that if the competitive value is positive, the commodity will also have competitive advantages. But if the competitive value is negative, the commodity won't also have cve advantages.

\section{RESULT AND DISCUSSION}

\subsection{SLQ Calculation Result}

Table3.1.

Basis and Non-Basis Sector Qualifications of Food and Beverage Sub-sectorin the 38 Cities/Regions of East Java Province

\begin{tabular}{|c|c|c|c|c|c|c|}
\hline \multirow{2}{*}{$\begin{array}{c}\text { Name ofthe } \\
\text { City/Region }\end{array}$} & \multicolumn{4}{|c|}{ SLQ } & \multirow{2}{*}{$\begin{array}{c}\text { Average } \\
\text { SLQ }\end{array}$} & $\begin{array}{c}\text { Additional } \\
\text { Information }\end{array}$ \\
\cline { 2 - 5 } & $\mathbf{2 0 1 2}$ & $\mathbf{2 0 1 3}$ & $\mathbf{2 0 1 4}$ & $\mathbf{2 0 1 5}$ & 1.27 & Basis \\
\hline Pacitan & 1.27 & 1.29 & 1.30 & 1.30 & 1.68 & Basis \\
\hline Ponorogo & 1.67 & 1.68 & 1.69 & 1.70 & 1.52 & Basis \\
\hline Trenggalek & 1.52 & 1.51 & 1.51 & 1.51 & 1.16 & Basis \\
\hline Tulungagung & 1.16 & 1.16 & 1.16 & 1.16 & 1.40 & Basis \\
\hline Blitar & 1.42 & 1.39 & 1.39 & 1.39 & Basis \\
\hline Kediri & 1.21 & 1.25 & 1.25 & 1.25 & 1.23 & Basis \\
\hline Malang & 1.14 & 1.14 & 1.12 & 1.12 & 1.13 & \\
\hline
\end{tabular}


International Journal of Advances in Scientific Research and Engineering (ijasre), Vol 5 (3), March-2019

\begin{tabular}{|c|c|c|c|c|c|c|}
\hline Lumajang & 1.98 & 1.94 & 1.90 & 1.90 & 1.94 & Basis \\
\hline Jember & 1.02 & 1.13 & 1.13 & 1.13 & 1.08 & Basis \\
\hline Banyuwangi & 1.88 & 1.88 & 1.88 & 1.89 & 1.88 & Basis \\
\hline Bondowoso & 1.35 & 1.39 & 1.43 & 1.42 & 1.37 & Basis \\
\hline Situbondo & 2.49 & 2.52 & 2.54 & 2.51 & 2.50 & Basis \\
\hline Probolinggo & 2.34 & 2.33 & 2.32 & 2.32 & 2.32 & Basis \\
\hline Pasuruan & 1.32 & 1.33 & 1.28 & 1.27 & 1.31 & Basis \\
\hline Sidoarjo & 1.25 & 1.26 & 1.28 & 1.27 & 1.27 & Basis \\
\hline Mojokerto & 1.50 & 1.51 & 1.49 & 1.51 & 1.50 & Basis \\
\hline Jombang & 1.18 & 1.19 & 1.21 & 1.21 & 1.18 & Basis \\
\hline Nganjuk & 1.20 & 1.20 & 1.22 & 1.25 & 1.20 & Basis \\
\hline Madiun & 1.87 & 1.89 & 1.92 & 1.89 & 1.87 & Basis \\
\hline Magetan & 1.87 & 1.87 & 1.87 & 1.86 & 1.86 & Basis \\
\hline Ngawi & 1.25 & 1.25 & 1.25 & 1.26 & 1.25 & Basis \\
\hline Bojonegoro & 0.89 & 0.88 & 0.89 & 0.90 & 0.87 & Non basis \\
\hline Tuban & 0.22 & 0.22 & 0.23 & 0.24 & 0.22 & Non basis \\
\hline Lamongan & 2.03 & 2.05 & 2.09 & 2.06 & 2.04 & Basis \\
\hline Gresik & 0.67 & 0.65 & 0.65 & 0.68 & 0.66 & Non basis \\
\hline Bangkalan & 0.85 & 0.86 & 0.87 & 0.85 & 0.85 & Non basis \\
\hline Sampang & 0.86 & 0.86 & 0.91 & 0.89 & 0.87 & Non basis \\
\hline Pamekasan & 1.26 & 1.28 & 1.27 & 1.25 & 1.26 & Basis \\
\hline Sumenep & 1.80 & 1.82 & 1.87 & 1.85 & 1.82 & Basis \\
\hline Kediri & 0.06 & 0.06 & 0.06 & 0.06 & 0.06 & Non basis \\
\hline Blitar & 1.24 & 1.28 & 1.30 & 1.33 & 1.27 & Basis \\
\hline Malang & 0.64 & 0.62 & 0.65 & 0.66 & 0.64 & Non basis \\
\hline Probolinggo & 0.71 & 0.71 & 0.72 & 0.72 & 0.71 & Non basis \\
\hline Pasuruan & 0.77 & 0.76 & 0.75 & 0.75 & 0.76 & Non basis \\
\hline Mojokerto & 0.95 & 0.93 & 0.91 & 0.89 & 0.92 & Non basis \\
\hline Madiun & 0.81 & 0.80 & 0.81 & 0.78 & 0.80 & Non basis \\
\hline Surabaya & 1.23 & 1.22 & 1.21 & 1.22 & 1.22 & Basis \\
\hline Batu & 2.53 & 2.54 & 2.55 & 2.48 & 2.52 & Basis \\
\hline
\end{tabular}

If the SLQ> 1, it means that sector is able to meet the economic needs of its region and is able to export its products beyond its economic boundaries. If theSLQ $<1$, it means thatthe sector is only able to meet the needs of local economy alone. There is also a possibility for them toimport when they are not able to meet their local needs.

\subsection{DLQCalculation Result}

Table3.2.

Values of Dynamic Location Quotient (DLQ)of 38 Cities/Regions in East Java Province

\begin{tabular}{|l|l|l|l|l|l|}
\hline \multirow{2}{*}{$\begin{array}{c}\text { Name of the } \\
\text { City/Region }\end{array}$} & \multicolumn{4}{c|}{ DLQ } & $\begin{array}{c}\text { Average } \\
\text { DLQ }\end{array}$ \\
\cline { 2 - 5 } & $\mathbf{2 0 1 2}$ & $\mathbf{2 0 1 3}$ & $\mathbf{2 0 1 4}$ & $\mathbf{2 0 1 5}$ & 3.66 \\
\hline Pacitan & 5.06 & 3.78 & 3.18 & 2.63 & 1.16 \\
\hline Ponorogo & 1.54 & 0.94 & 1.25 & 0.90 & 0.71 \\
\hline Trenggalek & 0.67 & 0.73 & 0.55 & 0.88 & 2.95 \\
\hline Tulungagung & 4.05 & 2.69 & 0.01 & 5.08 & 1.18 \\
\hline Blitar & 0.07 & 0.27 & 2.37 & 2.00 & 1.95 \\
\hline Kediri & 0.25 & 2.48 & 3.82 & 1.24 & 1.01 \\
\hline Malang & 1.76 & 0.35 & 1.16 & 0.79 & 0.93 \\
\hline Lumajang & 1.25 & 0.96 & 1.17 & 0.36 & 1.42 \\
\hline Jember & 2.31 & 1.44 & 1.71 & 0.24 & 0.95 \\
\hline Banyuwangi & 0.89 & 0.88 & 0.72 & 1.29 & 2.03 \\
\hline Bondowoso & 1.94 & 1.72 & 3.15 & 1.31 & 1.20 \\
\hline Situbondo & 1.54 & 1.11 & 1.38 & 0.77 & \\
\hline
\end{tabular}


International Journal of Advances in Scientific Research and Engineering (ijasre), Vol 5 (3), March-2019

\begin{tabular}{|l|l|l|l|l|l|}
\hline Probolinggo & 1.34 & 1.07 & 0.59 & 0.74 & 0.93 \\
\hline Pasuruan & 0.69 & 1.35 & 0.15 & 0.72 & 0.73 \\
\hline Sidoarjo & 1.16 & 1.38 & 1.81 & 0.46 & 1.20 \\
\hline Mojokerto & 0.64 & 0.48 & 0.46 & 1.32 & 0.72 \\
\hline Jombang & 3.65 & 3.42 & 2.26 & 2.07 & 2.85 \\
\hline Nganjuk & 2.78 & 1.67 & 1.45 & 1.77 & 1.92 \\
\hline Madiun & 2.05 & 1.46 & 0.89 & 0.86 & 1.31 \\
\hline Magetan & 1.16 & 0.93 & 0.94 & 1.01 & 1.01 \\
\hline Ngawi & 2.26 & 0.87 & 2.04 & 2.07 & 1.81 \\
\hline Bojonegoro & 1.50 & 0.50 & 0.42 & 0.73 & 0.79 \\
\hline Tuban & 3.52 & 0.82 & 2.27 & 1.80 & 2.10 \\
\hline Lamongan & 1.30 & 0.95 & 2.52 & 0.82 & 1.40 \\
\hline Gresik & 0.28 & 0.23 & 1.53 & 2.44 & 1.12 \\
\hline Bangkalan & 0.93 & 0.54 & 0.73 & 1.19 & 0.85 \\
\hline Sampang & 0.43 & 0.59 & 0.66 & 0.96 & 0.66 \\
\hline Pamekasan & 1.50 & 1.29 & 0.60 & 1.19 & 1.14 \\
\hline Sumenep & 1.73 & 1.44 & 2.08 & 0.68 & 1.48 \\
\hline Kediri & 3.47 & 2.31 & 1.77 & 1.50 & 2.26 \\
\hline Blitar & 4.51 & 1.83 & 2.00 & 1.01 & 2.34 \\
\hline Malang & 1.17 & 5.75 & 1.46 & 4.78 & 3.29 \\
\hline Probolinggo & 1.85 & 0.36 & 1.34 & 1.01 & 1.14 \\
\hline Pasuruan & 1.29 & 0.52 & 0.96 & 1.46 & 1.06 \\
\hline Mojokerto & 0.55 & 0.69 & 1.11 & 1.58 & 0.98 \\
\hline Madiun & 0.72 & 0.39 & 1.52 & 0.26 & 0.72 \\
\hline Surabaya & 1.25 & 1.95 & 0.93 & 0.54 & 1.17 \\
\hline Batu & 1.14 & 0.92 & 0.78 & 0.42 & 0.82 \\
\hline & & & & & \\
\hline
\end{tabular}

Based on Table

of DLQ > 1, it means the food and beverage industries in that area has a higher potential growth rate than other areas in East Java province. And if the value of DLQ $<1$, it means that the food and beverage industries in that area has a lower potential growth rate than other areas in East Java Province.

Table3.3.

The Calculation Results onCompetitive Value Componentof the Food and Beverage Sub-Sector in 38 Cities/Regions of East Java Province

\begin{tabular}{|c|c|c|c|c|c|c|}
\hline \multirow{2}{*}{$\begin{array}{l}\text { Name of the } \\
\text { City/Region }\end{array}$} & \multicolumn{4}{|c|}{ Cij } & \multirow{2}{*}{$\begin{array}{c}\text { Average } \\
\text { Cij }\end{array}$} & \multirow{2}{*}{ Result } \\
\hline & 2012 & 2013 & 2014 & 2015 & & \\
\hline Pacitan & -66.68 & $\begin{array}{l}-188.64 \\
\end{array}$ & -249.85 & -461.76 & -241.73 & $\mathrm{NO}$ \\
\hline Ponorogo & 241.29 & -70.48 & 128.76 & -157.00 & 35.64 & YES \\
\hline Trenggalek & -441.58 & -420.07 & -707.69 & -324.65 & -473.50 & $\mathrm{NO}$ \\
\hline Tulungagung & 2996.55 & 2125.51 & $\begin{array}{l}-7765.41 \\
\end{array}$ & 6590.40 & 986.76 & YES \\
\hline Blitar & -4054.01 & -3246.96 & 25.46 & -450.64 & -1931.54 & NO \\
\hline Kediri & -3818.58 & 1092.79 & 2629.65 & -1454.61 & -387.69 & $\mathrm{NO}$ \\
\hline Malang & 5678.81 & -8176.92 & 2169.16 & -2334.71 & -665.91 & $\mathrm{NO}$ \\
\hline Lumajang & 913.13 & 72.33 & 850.61 & -4681.40 & -711.33 & $\mathrm{NO}$ \\
\hline Jember & 4732.96 & 2823.52 & 3897.43 & -7927.81 & 881.53 & YES \\
\hline Banyuwangi & -232.56 & -298.61 & -1240.20 & 2432.66 & 165.32 & YES \\
\hline Bondowoso & 2828.00 & 929.79 & 621.89 & -1319.84 & 764.96 & YES \\
\hline Situbondo & 1657.19 & 1113.13 & 1726.96 & 333.31 & 1207.65 & YES \\
\hline Probolinggo & 2086.92 & 1169.39 & -1881.44 & -1144.64 & 57.56 & YES \\
\hline Pasuruan & 8739.58 & 35545.33 & -32443.04 & 18006.12 & 7462.00 & YES \\
\hline Sidoarjo & -43086.90 & -28088.71 & 24253.26 & -34910.85 & -20458.30 & $\mathrm{NO}$ \\
\hline Mojokerto & -3698.59 & -9095.70 & -9814.07 & 14734.20 & -1968.54 & $\mathrm{NO}$ \\
\hline Jombang & 1278.74 & 1298.99 & 11.39 & -373.14 & 554.00 & YES \\
\hline Nganjuk & 450.72 & -115.80 & -281.61 & -73.31 & -5.00 & $\mathrm{NO}$ \\
\hline
\end{tabular}


International Journal of Advances in Scientific Research and Engineering (ijasre), Vol 5 (3), March-2019

\begin{tabular}{|c|c|c|c|c|c|c|c|}
\hline \multirow{21}{*}{ Based on } & Madiun & 478.58 & 187.00 & -316.84 & -521.15 & -43.10 & $\mathrm{NO}$ \\
\hline & Magetan & -370.061 & -620.564 & -615.411 & -808.302 & -603.584 & $\mathrm{NO}$ \\
\hline & Ngawi & 83.73658 & -446.448 & 33.64069 & 60.69077 & -67.0949 & $\mathrm{NO}$ \\
\hline & Bojonegoro & 1849.945 & 533.2654 & 500.6976 & 108.405 & 748.0783 & YES \\
\hline & Tuban & 1294.538 & -520.63 & 835.4219 & 743.8471 & 588.2942 & YES \\
\hline & Lamongan & 1422.824 & 1057.909 & 3357.59 & 1229.376 & 1766.925 & YES \\
\hline & Gresik & -10405.4 & -13660.1 & -5203.62 & 25210.55 & -1014.64 & $\mathrm{NO}$ \\
\hline & Bangkalan & 202.4996 & -42.2876 & 52.49277 & -121.442 & 22.81575 & YES \\
\hline & Sampang & 40.90886 & -190.201 & 454.8354 & -185.053 & 30.12241 & YES \\
\hline & Pamekasan & 244.9159 & 226.7314 & -71.2423 & 295.628 & 174.0082 & YES \\
\hline & Sumenep & 693.8511 & 615.3487 & 1080.411 & -225.325 & 541.0715 & YES \\
\hline & Kediri & 393.07 & -383.726 & -892.858 & -1766.93 & -662.61 & $\mathrm{NO}$ \\
\hline & Blitar & 322.3687 & 120.8952 & 148.5451 & -33.0179 & 139.6978 & YES \\
\hline & Malang & -815.252 & -3781.9 & -3015.89 & -6211.49 & -3456.13 & $\mathrm{NO}$ \\
\hline & Probolinggo & 110.1889 & -430.153 & -0.91525 & -156.016 & -119.224 & $\mathrm{NO}$ \\
\hline & Pasuruan & -206.256 & -507.819 & -328.169 & -285.554 & -331.949 & $\mathrm{NO}$ \\
\hline & Mojokerto & -202.285 & -197.496 & -116.296 & -76.4999 & -148.144 & $\mathrm{NO}$ \\
\hline & Madiun & -30.8689 & -362.787 & 441.3646 & -830.871 & -195.791 & $\mathrm{NO}$ \\
\hline & Surabaya & 31245.67 & 24188.94 & 23838.09 & 62.6292 & 19833.83 & YES \\
\hline & Batu & 276.5545 & 199.3343 & 114.6496 & -295.748 & 73.6975 & YES \\
\hline & \multicolumn{7}{|c|}{ *YES $\quad$ : Has some competitive advantages } \\
\hline
\end{tabular}

Table3.3., if the value of $\mathrm{Cij}$ is positive, it means that area has somecompetitiveadvantages, and if the value of $\mathrm{Cij}$ isnegative, it means that area has no competitive advantages

\section{CONCLUSSIONS}

1. Based on the SLQ calculations, sub-sector offood and beveragesinthe region of Bojonegoro, Tuban, Gresik, Bangkalan, and Sampang, and the city ofKediri, Malang, Probolinggo, Pasuruan, Mojokerto, and Madiun is a non-basis sector, while in other regions/cities, sub-sector offood and beverage becomes the basis sector. And based on the value of DLQ,the region of Trenggalek, Lumajang, Banyuwangi, Probolinggo, Pasuruan, Mojokerto, Bojonegoro, Bangkalan, Sampang, and the city of Mojokerto, Madiun, and Batu has a higher potential growth rate than other areas.

2. Based on the combination of SLQ and DLQ values, sub-sector of food and beverage is becoming theleading industriesin the region of Pacitan, Ponorogo, Tulungagung, Blitar, Kediri, Malang, Jember, Bondowoso, Situbondo, Sidohigherrarjo, Jombang, Nganjuk, Madiun, Magetan, Ngawi, Lamongan, Pamekasan, and Sumenep, and in the city of Blitar and Surabaya. Sub-sector of food and beverage is becoming thekey industriesin the region ofTuban and Gresik, and in the city of Kediri, Malang, Probolinggo, and Pasuruan. Sub-sector of food and beverage is becoming theprospective industriesin the region ofTrenggalek, Lumajang, Banyuwangi, Probolinggo, Pasuruan, and Mojokerto, and in the city of Batu. Sub-sector of food and beverage is becoming theunderdeveloped industriesinthe region of Bojonegoro,Bangkalan, and Sampang. and the city of Mojokerto and Madiun.

3. Based on the calculation on competitive value components, food and beverage industry commodity has some competitive advantages in the region of Ponorogo, Tulungagung, Jember, Banyuwangi,Bondowoso, Situbondo, Probolinggo, Pasuruan, Jombang, Bojonegoro, Tuban, Lamongan, Bangkalan, Sampang, Pamekasan, Sumenep, andBlitar, and in the city of Surabaya andBatu, while commodities in other districts do not have any competitive advantage. Therefore the industries need to be empowered in term of research and development.

\section{BIBLIOGRAPHY}

1. Beenstock, Michael, and Felsenstein, Daniel. 2009. Marshallian Theory Of Regional Agglomeration. Working Paper No. 1607.

2. Berger, Thor. 2001. Agglomeration Externalities and Growth in Urban Industries. The Review of Economic, Vol. 29 (3): $155-173$. 
International Journal of Advances in Scientific Research and Engineering (ijasre), Vol 5 (3), March-2019

3. Irmawati, Setyani. 2016. The Analysis on Leading Industries in Central Java Province. Journal of Economics and Policy, Vol. 8 (2): 215-228.

4. Kadariyah. 1994. Teori Ekonomi Mikro. Jakarta : Fakultas Ekonomi Universitas Indonesia.

5. Kuncoro, Mudrajad. 2000. Konsentrasi Geografis Industri Manufaktur di Greater Jakarta dan Bandung: Menuju Satu Daerah Aglomerasi?. Jurnal Ekonomi dan Bisnis Indonesia, Vol. 17 (1): 5-17.

6. Kurniati, Yati, dan Yanfitri. 2010. Dinamika Industri Manufaktur dan Respon Terhadap Siklus Bisnis. Buletin Ekonomi Moneter dan Perbankan Bank Indonesia.

7. Malik, Muhammad. 2013. Ekonomi Industri. Jakarta: Media Pustaka.

8. Mukiyono, Aris. dkk. 2017. Agglomeration of Food and Beverage Industries in Regencies and Cities in East Java Province. Journal of Economics and Sustainable Development, Vol. 8 (8): 186-199.

9. Pasaribu, Rowland B. F., 2012. Kebijakan Persaingan, Daya Saing, Liberalisasi, Globalisasi, Dan Regionalisasi di Indonesia. Jurnal Ekonomi Pembangunan Indonesia, Vol. 3 (2): 121-131.

10. Putra, Ichsan. 2010. Pengembangan Kompetensi Inti Daerah Melalui Analisis Kluster Industri Kecil Di Sulawesi Tenggara (2005-2009). Jurnal Ekonomi Pembangunan, Vol. 3 (5): 197 - 212.

11. Santoso, Eko. dkk. 2012. Analisis Keterkaitan Wilayah secara Sektoral Ditinjau dari Sektor Unggulan Kawasan GKS Plus terhadap Jawa Timur : Implikasinya terhadap Pengembangan Perkotaan. Seminar Nasional CITIES 2012, hal.1-15.

12. Schmutzler, A. 1999. The New Economic Geography. Journal of Economic Surveys. Vol.13(2):549-57 
International Journal of Advances in Scientific Research and Engineering (ijasre), Vol 5 (3), March-2019 